\title{
Inhalational and local anesthetics reduce tactile and thermal responses in mimosa pudica
}

Avaleigh Milne,

Travis Beamish

Purpose: In reaction to a variety of stimuli, the sensitive plant mimosa pudica closes its leaflets and drops its stems. The objective was to investigate the effects of anaesthetics on the reaction of mimosa pudica to a variety of stimuli.

Methods: The ability of the plants leaflets to close $(n=4, Q 5 \mathrm{~min}$.) was tested after exposure to halothane $4 \%$ and $6 \mathrm{~L} \cdot \mathrm{min}^{-1} \mathrm{O}_{2}$, or $6 \mathrm{~L} \cdot \mathrm{min}^{-1} \mathrm{O}_{2}$ Lidocaine $2 \%$ or vehicle were administered through the roots, cut stems, or sprayed on the leaves $(n=4)$. The test consisted of stimulating the leaves, by burning their tips (lidocaine experiments) or touching them with a metal rod (halothane); the closing of the leaflets, or the lack thereof was then observed.

Results: After 15 min exposure to halothane, the mimosas had slow and incomplete reactions to tactile stimulation. Following 20 min exposure, the plants had no visible reaction to touch, a stimulus which would normally cause the collapse of the entire leaf. After one minute, mimosa leaves sprayed with lidocaine had no reaction to a lit match being touched to the tips of the leaves, contrary to the control in which the leaves collapsed completely. After exposure to lidocaine $2 \%$ through the roots and cut stems, the mimosa's reactivity gradually decreased; after four hours the leaves were insensitive or had slow reaction to tactile stimuli.

Conclusions: Inhalational and local anesthetics inhibited motor mechanisms of the mimosa plant. This may be a model to elucidate the mechanisms of action of anesthetics.

Objectif : En réaction à divers stimuli, la sensitive (mimosa pudica) replie ses feuilles et laisse tomber sa tige. L'objectif était d'examiner les effets d'anesthésiques sur la réaction de la sensitive à une variété de stimuli.

Méthode : On a testé la rétractilité des feuilles ( $n=4, Q 5 \mathrm{~min}$.) après l'exposition à de l'halothane $4 \%$ et à $6 \mathrm{~L} \cdot \mathrm{min}^{-1} \mathrm{~d}^{\prime} \mathrm{O}_{2}$, ou à $6 \mathrm{~L} \cdot \mathrm{min}^{-1} \mathrm{~d}^{\prime} \mathrm{O}_{2}$ De la lidocaïne $2 \%$ ou un excipient ont été administrés par des racines, des coupures à la tige ou des pulvérisations sur les feuilles $(n=4)$. Le test consistait à stimuler les feuilles, en brûlant leur pointe (expériences avec lidocaïne) ou à les toucher avec une tige de métal (halothane); la rétraction ou non des feuilles a été alors notée.

Résultats : Après 15 min d'exposition à l'halothane, les réactions étaient lentes et incomplètes à une stimulation tactile. Après $20 \mathrm{~min}$, le mimosa n'avait pas de réaction perceptible au toucher, ce qui aurait normalement provoqué une rétraction complète de la feuille. Après une minute, les feuilles ne réagissaient pas au feu d'une allumette qui en touchait la pointe, contrairement aux feuilles témoin qui se repliaient tout à fait. Après l'exposition à la lidocaïne $2 \%$ au travers des racines ou de coupures à la tige, la réactivité de la sensitive a diminué graduellement : après $4 \mathrm{~h}$, les feuilles étaient insensibles ou riavaient pas de réaction à des stimuli tactiles.

Conclusion : Les anesthésiques en inhalation et les anesthésiques locaux ont inhibé la motricité de la sensitive. L'expérience peut servir de modèle pour élucider les modes d'action des anesthésiques.

From the Kingston Collegiate and Vocational Institute, Departments of Anaesthesia and Pharmacology and Toxicology, Queen's University, Kingston, Ontario, Canada.

Address correspondence to: Avaleigh Milne, 108 Albert St, Kingston, Ontario, K7L 3V2 Canada. Phone: 613-542-9988; Fax: 613-5481375

Presented in part at the Canadian Anaestherists' Society Annual Meeting, Vancouver 1997.

Accepted for publication December 19, 1998 
$\mathrm{T}$ HE sensitive plant mimosa pudica has a visible reaction, consisting of the closing of the plant's leaflets and dropping of the stems, to a variety of stimuli including touch, light and temperature. The motor mechanism of this reaction is due to unloading of the contents of the phloem, a part of the plant's vascular system, and is caused by opening of potassium, calcium and chloride channels in specialized motor cells, called pulvinar cells. This stimulation causes the cells to be evacuated of liquids, resulting in them being too weak to support the stem or leaflet, which will then fold. ${ }^{1}$ In 1878 , Claude Bernard studied the effects of ether on the mimosa, and found that it rendered the plant insensitive after being exposed for 25 min. ${ }^{2}$ The objective of this study was to investigate the effects of inhalational and local anesthetics on mimosa's reaction to a variety of stimuli in order to test whether this may be a useful model to further elucidate the mechanism of action of anesthetics.

\section{Methods}

In a series of experiments the reactions of the mimosa to different stimuli under normal conditions were tested. The stimuli which caused the greatest reactions were touching the leaves and putting a lit match to the end of one of the leaflets. These stimuli were then used in subsequent experiments to test the effects of anesthetics. The reactions of plants to touch $(\mathrm{n}=4, Q 5 \mathrm{~min})$ were tested throughout $20 \mathrm{~min}$ of exposure to halothane $4 \%$ and 6 $\mathrm{L} \cdot \mathrm{min}^{-1} \mathrm{O}_{2}$, or $6 \mathrm{~L} \cdot \mathrm{min}^{-1} \mathrm{O}_{2}$ as control. The test consisted of stimulating the leaves by touching them with a metal rod; the closing of the leaflets, or the lack thereof was then observed. Plants were housed in a Plexiglass box with an airtight port through which the stimulus was delivered. To test the mimosa's reaction under the effect of a local anesthetic, lidocaine $2 \%$ or normal saline was administered through the roots or cur stems of plants $(n=4)$, or a $12 \%$ lidocaine solution was sprayed directly on the leaves $(n=4)$. To administer lidocaine through the roots, the exposed roots of each mimosa were placed in $10 \mathrm{~mL}$ of the $2 \%$ lidocaine solution for four hours, testing the reactivity of the mimosas every $30 \mathrm{~min}$. By the end of the experiment, approximately one $\mathrm{mL}$ of the solution had been absorbed by the plants' roots. The cut stems were also placed in $10 \mathrm{~mL}$ lidocaine $2 \%$ solution. Minimal amounts of the solution were absorbed by the time the anestheric had an effect. The plants were then stimulated by burning the tips of the leaflets; the closing or lack of closure of the leaflets was then observed.

\section{Results}

Figure 1 demonstrates the open mimosa leaf and the closed mimosa leaf following stimulation. The normal outspread position of the leaf is approximately $10^{\circ}$ above the horizon; upon stimulation it executes an angular fall of approximately $100^{\circ}$ in one to two seconds. ${ }^{3}$ With the lit match stimulus the reaction was spread to the other leaves and stems of the plant so that they also folded.

After $15 \mathrm{~min}$ of exposure to halothane $4 \%$, the mimosas had very slow and incomplete reactions to being touched. Following $20 \mathrm{~min}$ exposure, the plants had no visible reaction to touch, a stimulus which would normally cause collapse of the entire leaf (Figure 2). The mimosas tested in the $\mathrm{O}_{2}$ control group reacted normally.

The lidocaine spray had a more immediate effect on the leaves of the mimosa; after one minute those which were sprayed had no reaction to a lit match being touched to the tips of the leaves, contrary to controls in which the leaves collapsed completely. After exposure to lidocaine $2 \%$ through the roots and cut stems, the mimosa's reaction was slow and incomplete. After four hours of soaking in the solution, plants were either completely insensitive $(n=3)$ or had a very slow and incomplete reaction $(n=1)$. Soaking in normal saline $(n=4)$ had no visible effect on reaction to stimuli (Figure 3).

Although recovery time was not tested specifically, whole plants recovered their normal reactivity by the following day.

\section{Discussion}

The major finding of this study was that the inhalational and local anesthetics used in these experiments had an obvious and reversible effect in preventing the motor mechanisms of the sensitive plant mimosa pudi$c a$. In the past some regarded plant sensitivity as evidence of structures similar to nerves, and some stretched generalization beyond credibility by suggesting that the sensitive plant had a neural apparatus, $a$ brain and cerebellum. ${ }^{3}$ However, Sibaoka demon-

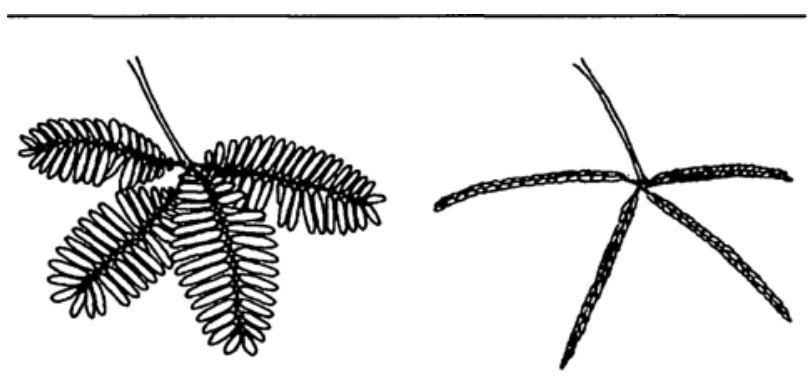

FIGURE 1 Normal open mimosa leaf and the closed leaf after stimulation. 


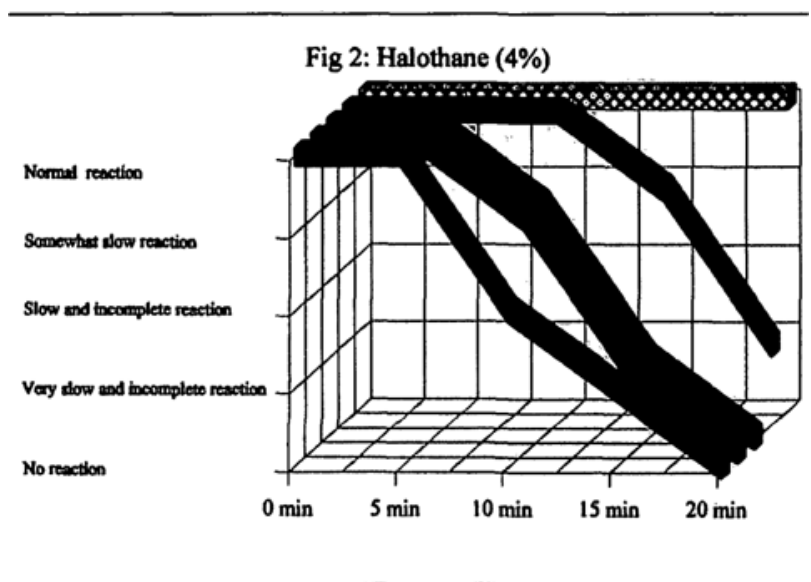

FIGURE 2 Exposure of mimosa plants to halothane $4 \%$ in $\mathrm{O}_{2}$ $(n=4)$ or $O_{2}(n=4)$ over time with respect to reactivity to touch The checkered line represents plants exposed to $6 \mathrm{~L} \cdot \mathrm{min}^{-1} \mathrm{O}_{2}$ $(n=4)$.

Each grey line represents a plant exposed to $6 \mathrm{~L} \cdot \mathrm{min}^{-1} \mathrm{O}_{2}$ with halothane $4 \%$.

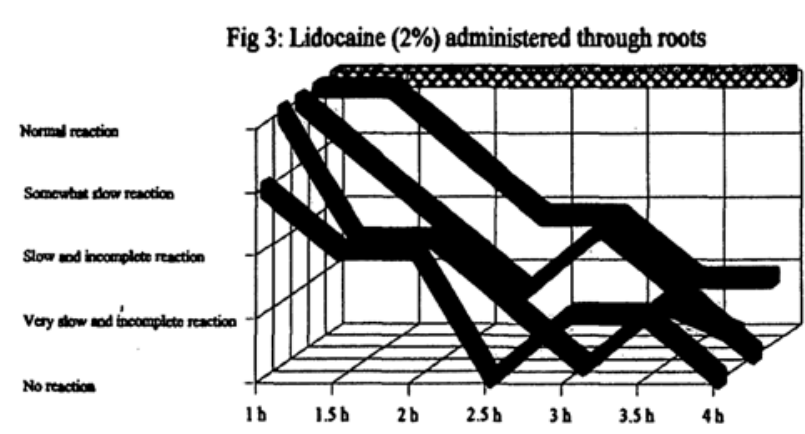

FIGURE 3 Soaking the mimosa roots in a lidocaine $2 \%$ solution $(n=4)$ or saline $(n=4)$ over four hours with respect to reactivity to touch.

The checkered line represents plants exposed to normal saline $(n=4)$.

Each grey line represents a plant exposed to lidocaine $2 \%$.

strated that transmission of electric signals through the petiole of mimosa pudica showed characteristics similar to action potentials in nerves. ${ }^{4}$ These action potentials may play an important role in coordinating physiological activities over long distances within the same plant. Plant cells have a resting potential with a negative charge on the inner side of the plasma membrane with proteins forming ionic channels which change in response to heat, touch, light or other stimuli. ${ }^{1}$ Taking into account the similarities between the physiology of this sensitive plant and humans, and the fact that general anesthetics are now thought to act on proteins in nerve membranes ${ }^{5}$ and local anesthetics on sodium channels in nerve membranes, it is not surprising that anesthetics would effect phloem unloading and thus reactivity in this sensitive plant.

In summary, the inhalation and local anesthetics used in these experiments had an obvious effect in preventing the motor mechanisms of the sensitive plant mimosa pudica. This may be a useful model to further elucidate the mechanisms of action of general and local anesthetics.

\section{Acknowledgments}

The authors wish to thank E. Turcke and Drs. D. Layzell, K. Jhamandas, K. Wynne-Edwards, R. Henry and $\mathrm{B}$. Milne for their advice and assistance.

\section{References}

1 Fromm J. Control of phloem unloading by action potentials in mimosa. Physiologia Plantarum 1991; 83: 529-33.

2 Bernard C. Lectures on Phenomena of Life Common to Animals and Plants. Paris: J.-B. Bailliere and Son, 1878.

3 Bose JC. The Motor Mechanism of Plants. London: Longmans, Green and Co., 1928.

4 Sibaoka T. Action potentials in plant organs. Symp Soc Exp Biol 1996; 20: 49-73.

5 Franks NP, Lieb WR. Molecular and cellular mechanisms of general anaesthesia. Nature 1994; 367: $607-14$. 